Supporting Information for:

\title{
Self-assembled Fluorescent Hexaazatriphenylenes That Act as a Light-harvesting Antenna
}

Tsutomu Ishi-i, ${ }^{, \dagger, \ddagger}$ Koh-ichi Murakami, ${ }^{\S}$ Yusuke Imai, ${ }^{\Uparrow}$ Shuntaro Mataka ${ }^{*}{ }^{\dagger}$

Table of contents:

S-FIGURE 1. UV/Vis spectra of $6 \mathbf{c}$ in octane at (a) $1.0 \mathrm{mM}$, (b) $0.1 \mathrm{mM}$, and (c) $0.01 \mathrm{mM}$ in the range of the temperature at $20,40,60$, and $75^{\circ} \mathrm{C}$.

S-FIGURE 2. UV/Vis spectra of $6 \mathbf{6}$ in (a) hexane, (b) cyclohexane, and (c) chloroform at 20 ${ }^{\circ} \mathrm{C}$ in the range of concentration at $0.01,0.1$, and $1.0 \mathrm{mM}$.

S-FIGURE 3. UV/Vis spectra of $\mathbf{6 b}$ in (a) cyclohexane and (b) chloroform at $20{ }^{\circ} \mathrm{C}$ in the range of concentration at $0.01,0.1$, and $1.0 \mathrm{mM}$.

S-FIGURE 4. UV/Vis spectra of $\mathbf{6 d}$ in (a) hexane and (b) chloroform at $20{ }^{\circ} \mathrm{C}$ in the range of concentration at $0.01,0.1$, and $1.0 \mathrm{mM}$.

S-FIGURE 5. CD spectra of $\mathbf{6 d}$ in hexane at $20{ }^{\circ} \mathrm{C}$ at $0.1 \mathrm{mM}(0.1 \mathrm{~cm}$ width cell $)$ and $1.0 \mathrm{mM}$ (0.01 cm width cell).

S-FIGURE 6. Steady-state fluorescence spectra of $6 \mathbf{a}$ at $20{ }^{\circ} \mathrm{C}$ in (a) hexane $\left(\lambda_{\mathrm{ex}}=389 \mathrm{~nm}\right)$ and $(\mathrm{b})$ chloroform $\left(\lambda_{\mathrm{ex}}=410 \mathrm{~nm}\right)$ in the range of concentration at $0.01,0.1$, and $1.0 \mathrm{mM}$.

S-FIGURE 7. Steady-state fluorescence spectra of $\mathbf{6 b}$ at $20{ }^{\circ} \mathrm{C}$ in (a) cyclohexane $\left(\lambda_{\text {ex }}=392\right.$ $\mathrm{nm})$ and $(\mathrm{b})$ chloroform $\left(\lambda_{\mathrm{ex}}=408 \mathrm{~nm}\right)$ in the range of concentration at $0.01,0.1$, and $1.0 \mathrm{mM}$.

S-FIGURE 8. Steady-state fluorescence spectra of $\mathbf{6 d}$ at $20{ }^{\circ} \mathrm{C}$ in (a) hexane $\left(\lambda_{\mathrm{ex}}=387 \mathrm{~nm}\right)$ and (b) chloroform $\left(\lambda_{\text {ex }}=406 \mathrm{~nm}\right)$ in the range of concentration at $0.01,0.1$, and $1.0 \mathrm{mM}$. 
S-FIGURE 9. ${ }^{1} \mathrm{H}$ NMR spectra of $6 \mathbf{c}$ in cyclohexane- $d_{12}$ at $20{ }^{\circ} \mathrm{C}$ in the range of concentration of (a) 0.01, (b) 0.1, (c) 0.5, (d) $1.0 \mathrm{mM}$.

S-FIGURE 10. ${ }^{1} \mathrm{H}$ NMR spectra of $\mathbf{6 b}$ in cyclohexane- $d_{12}$ at $20{ }^{\circ} \mathrm{C}$ in the range of concentration of (a) 0.005 , (b) 0.01 , (c) 0.05 , (d) 0.1 , (e) 0.5 , (f) $1.0 \mathrm{mM}$.

S-FIGURE 11. van't Hoff plot for the self-association of $\mathbf{6 c}$ in octane- $d_{18}$ : the correlation coefficient $(R)$ is 0.999 where $\Delta H^{0}$ is $-29.3 \mathrm{~kJ} \mathrm{~mol}^{-1}$ and $\Delta S^{0}$ is $-22.8 \mathrm{~J} \mathrm{~mol}^{-1} \mathrm{~K}^{-1}$.

S-FIGURE 12. UV-vis and fluorescence spectra of $\mathbf{6 b}$ and 7 at the spin-coating film at $20{ }^{\circ} \mathrm{C}$. The fluorescence spectra were obtained by excitation at $395 \mathrm{~nm}$.

S-FIGURE 13. UV-vis spectra of 6a/7/8 mixtures with 100:0:0 (black line), 100:5:0 (red line), 100:5:5 (blue line), and 0:0:5 (green line) molar ratio in the spin-coating film at $20{ }^{\circ} \mathrm{C}$.

S-FIGURE 14. Fluorescence spectra excited at the HAT chromophore (395 nm) of 6a/7 mixtures with 100:0, 100:1, 100,10, and 0:10 molar ratio in the spin-coating film (from chloroform solution) at $20{ }^{\circ} \mathrm{C}$.

S-FIGURE 15. Absorption and excitation spectra of $\mathbf{6 a} / \mathbf{7}$ mixture with 100:5 at the spin-coating film (from cyclohexane solution) at $20{ }^{\circ} \mathrm{C}$. The excitation spectrum was monitored at the PDI chromophore (at $645 \mathrm{~nm}$ ). The energy transfer efficiency was estimated to be ca. $80 \%$.

S-TABLE 1. UV-vis spectral data for $6 c$ in octane.

S-TABLE 2. Fluorescence lifetime for 6a (in hexane), $6 \mathbf{b}$ (in cyclohexane), and 6c (in hexane). 

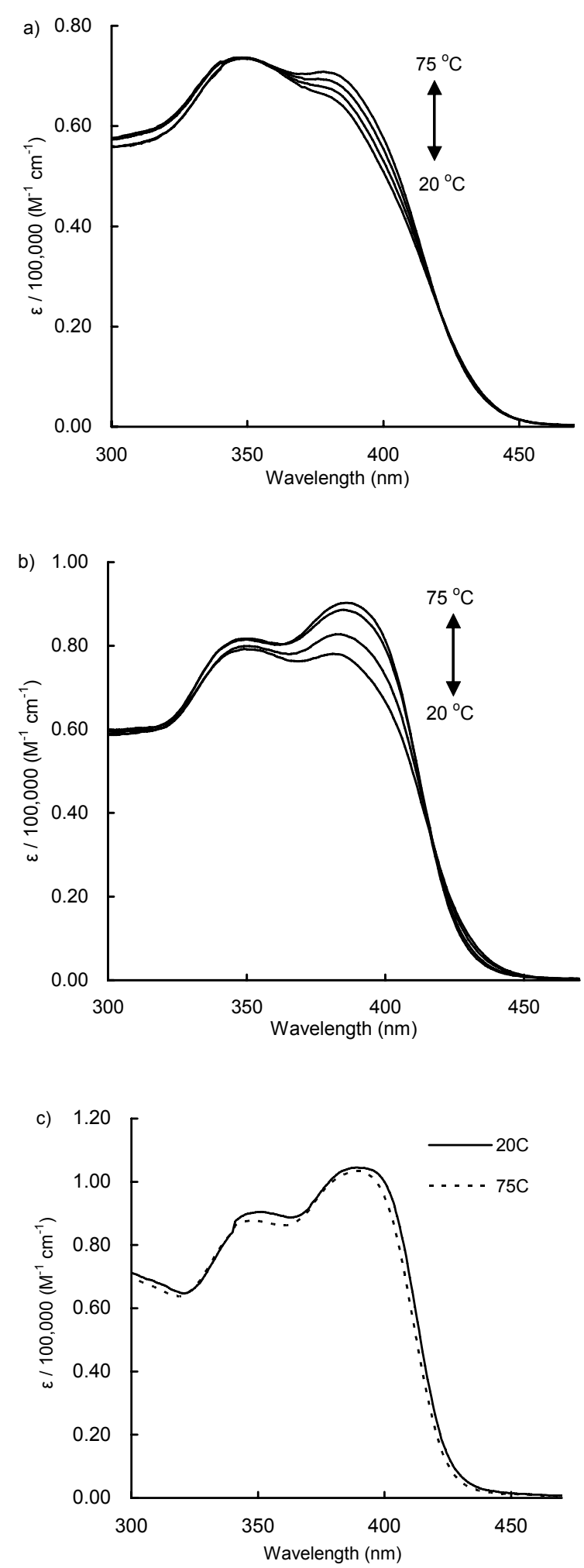

S-FIGURE 1. UV/Vis spectra of $6 \mathrm{c}$ in octane at (a) $1.0 \mathrm{mM}$, (b) $0.1 \mathrm{mM}$, and (c) $0.01 \mathrm{mM}$ in the range of the temperature at $20,40,60$, and $75^{\circ} \mathrm{C}$. 

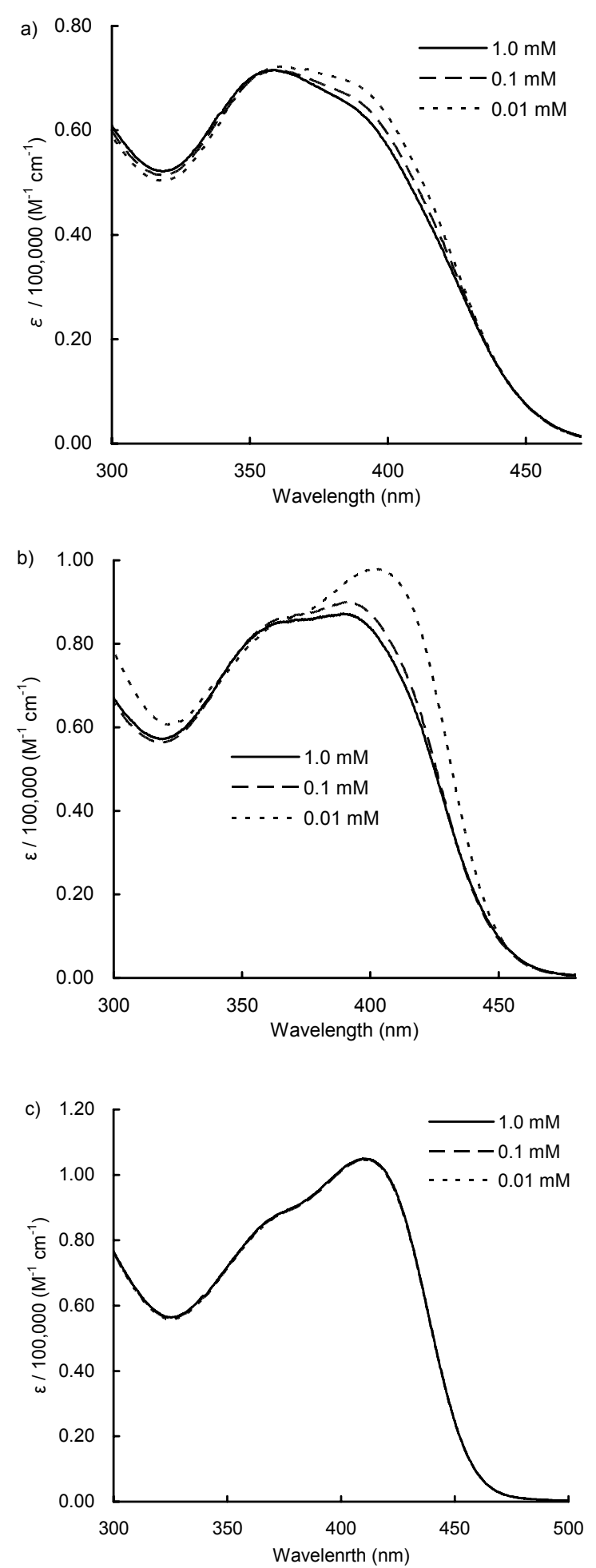

S-FIGURE 2. UV/Vis spectra of 6 a in (a) hexane, (b) cyclohexane, and (c) chloroform at $20{ }^{\circ} \mathrm{C}$ in the range of concentration at $0.01,0.1$, and $1.0 \mathrm{mM}$. 

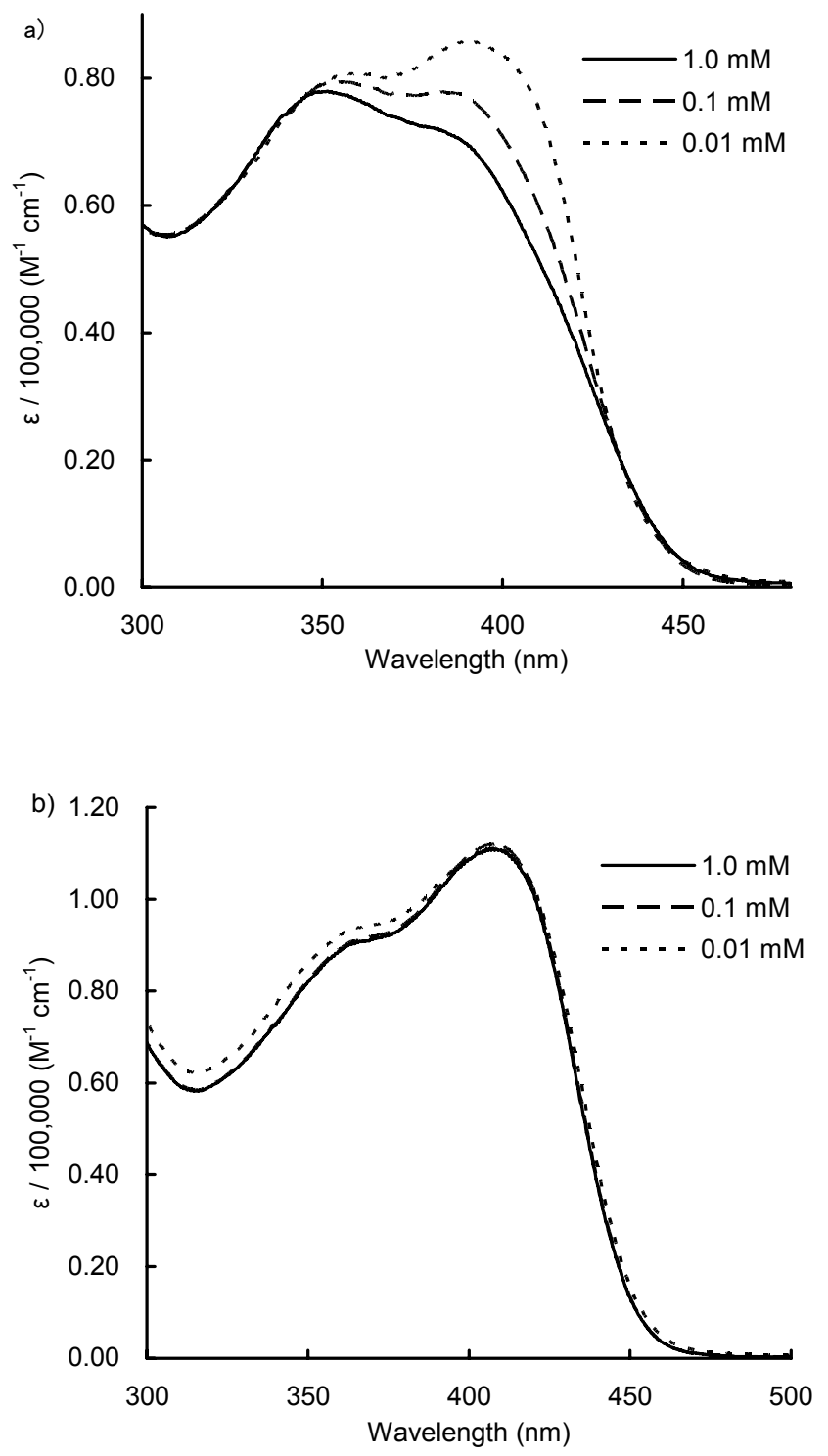

S-FIGURE 3. UV/Vis spectra of $\mathbf{6 b}$ in (a) cyclohexane and (b) chloroform at $20{ }^{\circ} \mathrm{C}$ in the range of concentration at $0.01,0.1$, and $1.0 \mathrm{mM}$. 

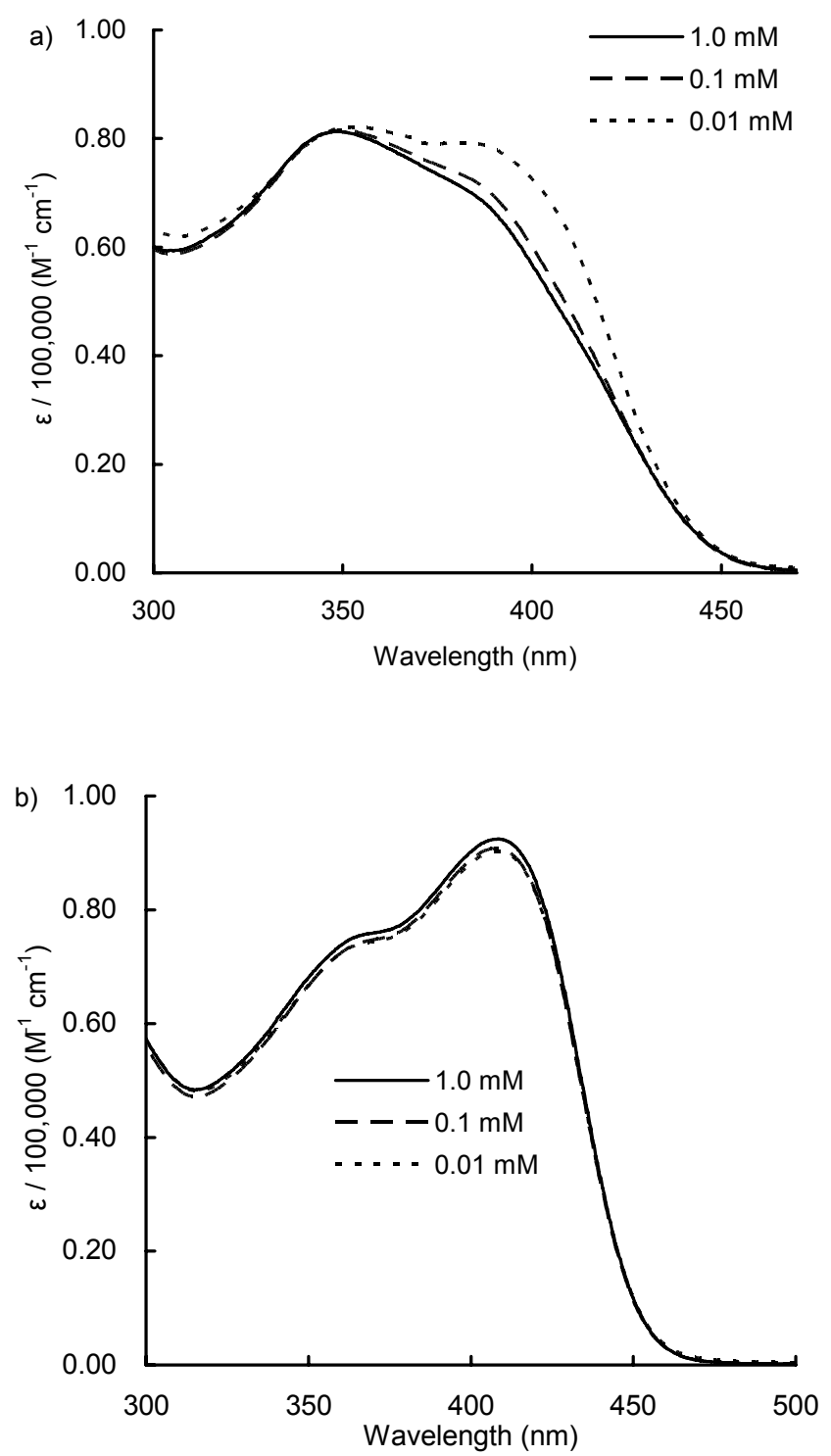

S-FIGURE 4. UV/Vis spectra of $\mathbf{6 d}$ in (a) hexane and (b) chloroform at $20{ }^{\circ} \mathrm{C}$ in the range of concentration at $0.01,0.1$, and $1.0 \mathrm{mM}$. 


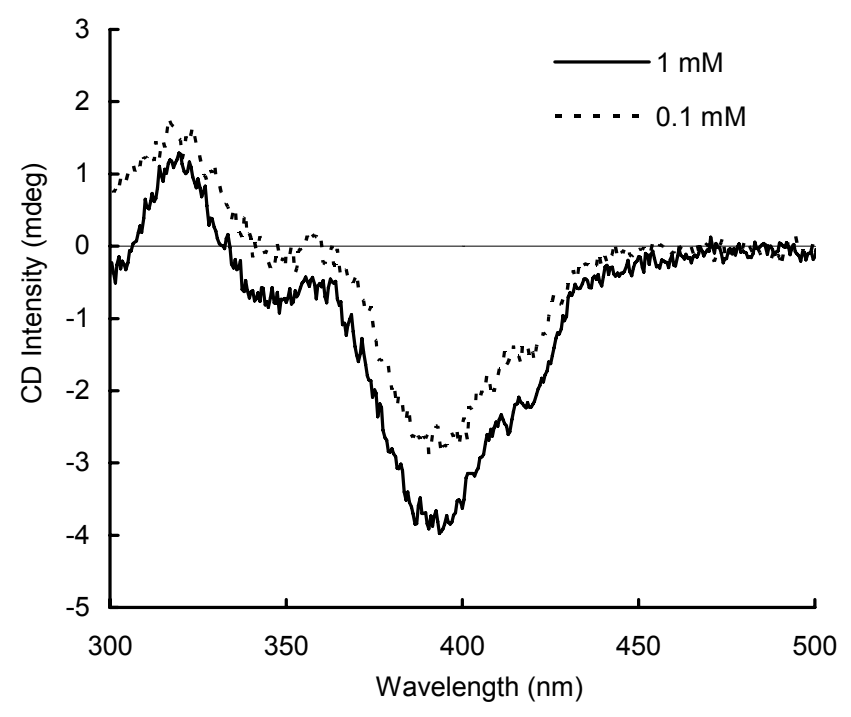

S-FIGURE 5. $\mathrm{CD}$ spectra of $\mathbf{6 d}$ in hexane at $20{ }^{\circ} \mathrm{C}$ at $0.1 \mathrm{mM}(0.1 \mathrm{~cm}$ width cell $)$ and $1.0 \mathrm{mM}(0.01 \mathrm{~cm}$ width cell). 

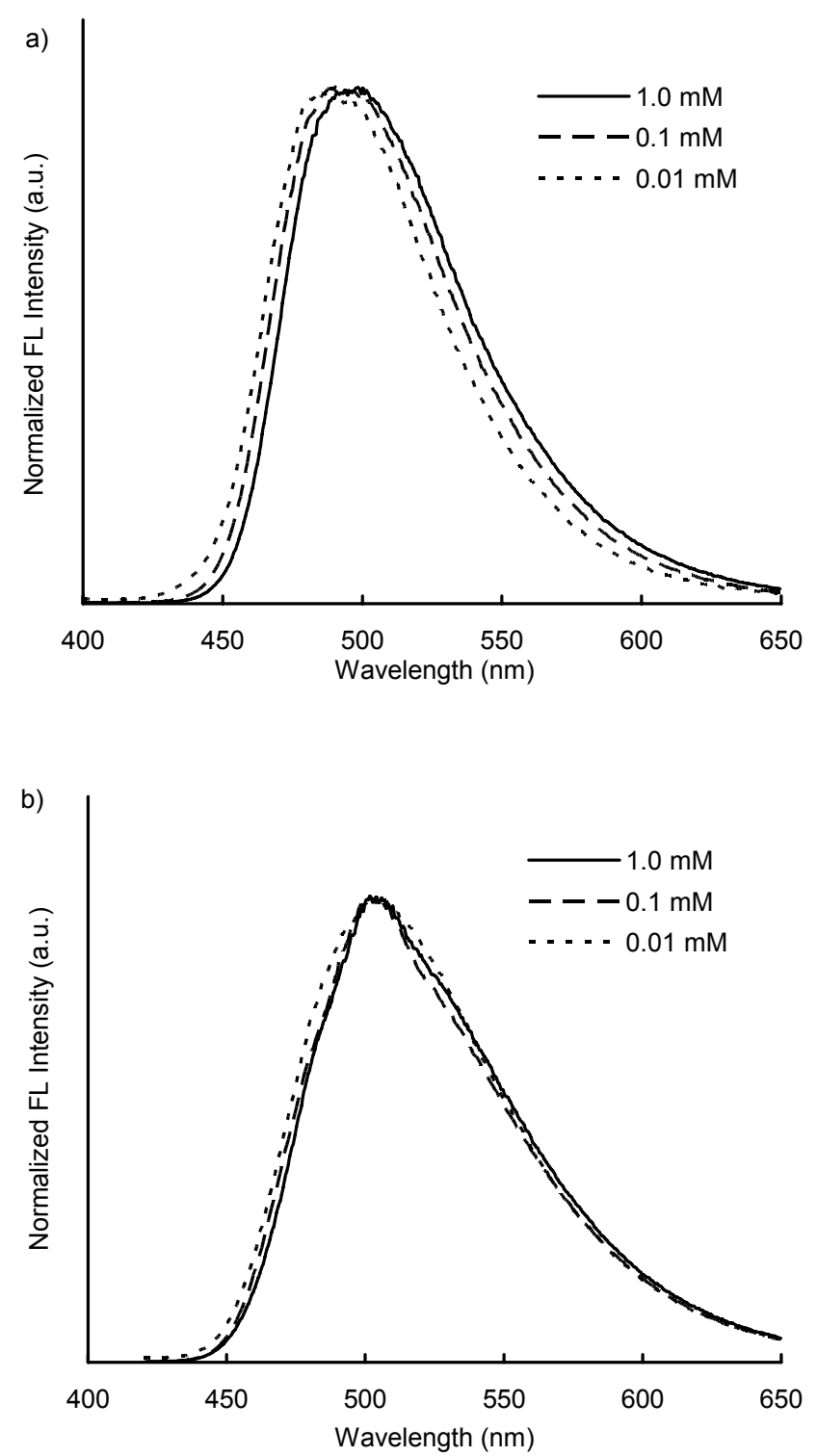

S-FIGURE 6. Steady-state fluorescence spectra of 6 a at $20{ }^{\circ} \mathrm{C}$ in (a) hexane $\left(\lambda_{\mathrm{ex}}=389 \mathrm{~nm}\right)$ and (b) chloroform $\left(\lambda_{\mathrm{ex}}=410 \mathrm{~nm}\right)$ in the range of concentration at $0.01,0.1$, and $1.0 \mathrm{mM}$. 

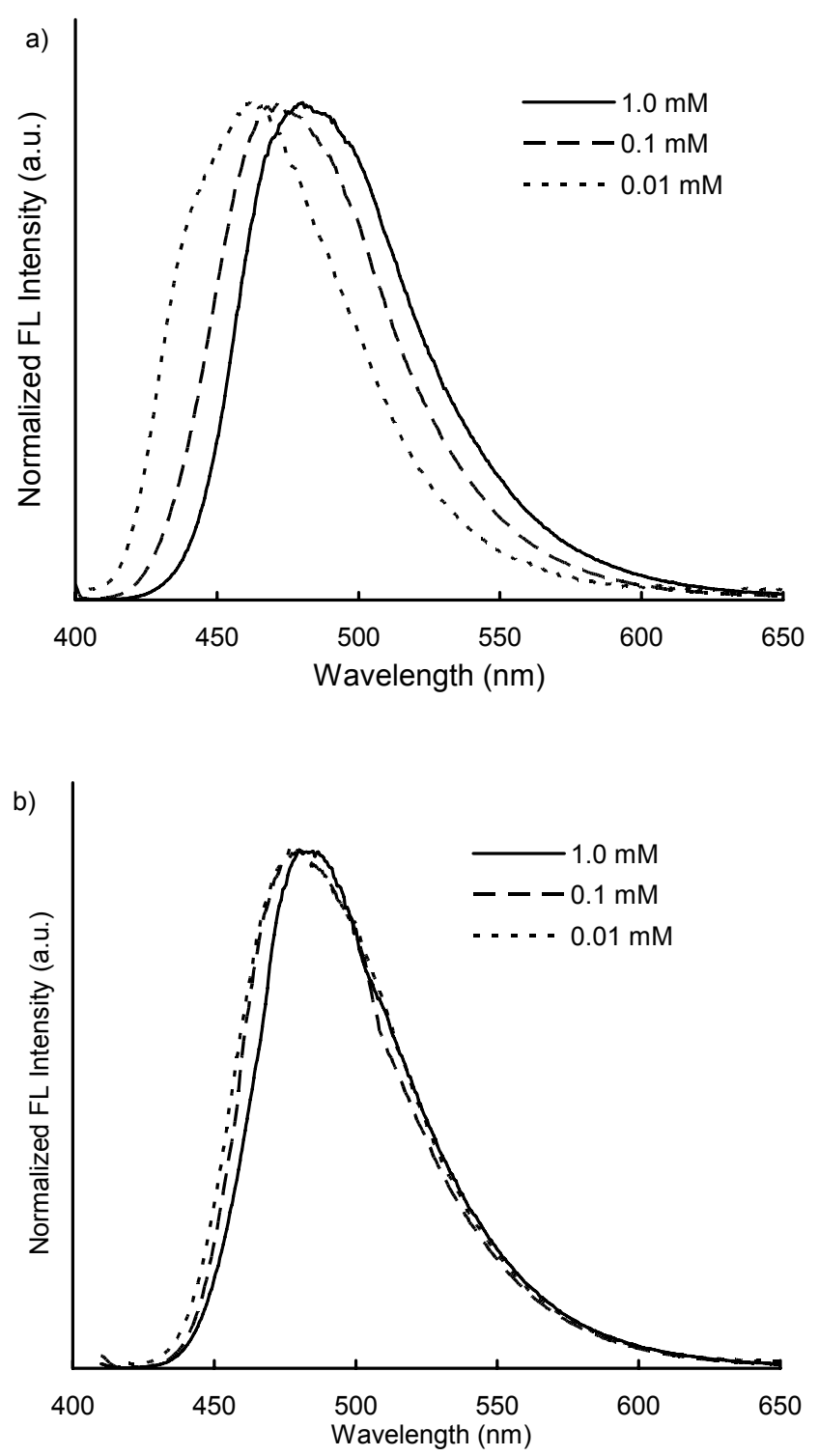

S-FIGURE 7. Steady-state fluorescence spectra of $\mathbf{6 b}$ at $20{ }^{\circ} \mathrm{C}$ in (a) cyclohexane $\left(\lambda_{\mathrm{ex}}=392 \mathrm{~nm}\right)$ and (b) chloroform $\left(\lambda_{\mathrm{ex}}=408 \mathrm{~nm}\right)$ in the range of concentration at $0.01,0.1$, and $1.0 \mathrm{mM}$. 

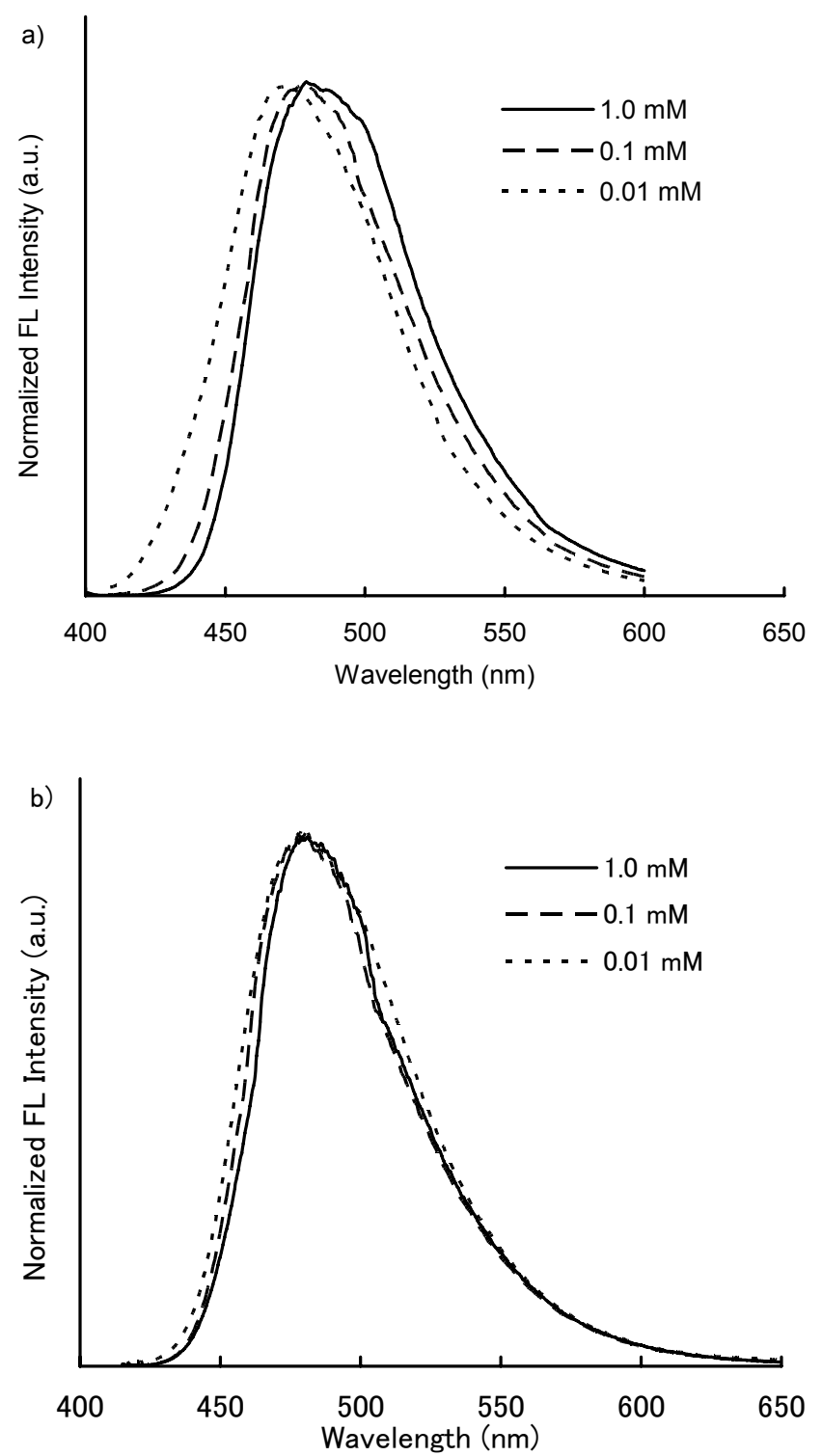

S-FIGURE 8. Steady-state fluorescence spectra of $\mathbf{6 d}$ at $20{ }^{\circ} \mathrm{C}$ in (a) hexane $\left(\lambda_{\mathrm{ex}}=387 \mathrm{~nm}\right)$ and (b) chloroform $\left(\lambda_{\mathrm{ex}}=406 \mathrm{~nm}\right)$ in the range of concentration at $0.01,0.1$, and $1.0 \mathrm{mM}$. 


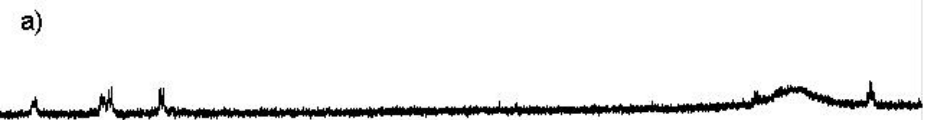

b)

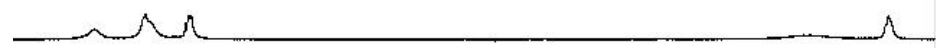

c)
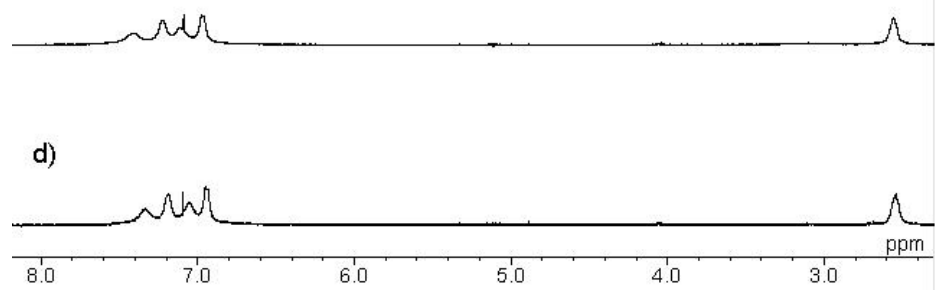

S-FIGURE 9. ${ }^{1} \mathrm{H}$ NMR spectra of $6 \mathbf{c}$ in cyclohexane- $d_{12}$ at $20{ }^{\circ} \mathrm{C}$ in the range of concentration of (a) 0.01, (b) 0.1, (c) 0.5, (d) $1.0 \mathrm{mM}$.

a)

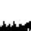

b)

c)
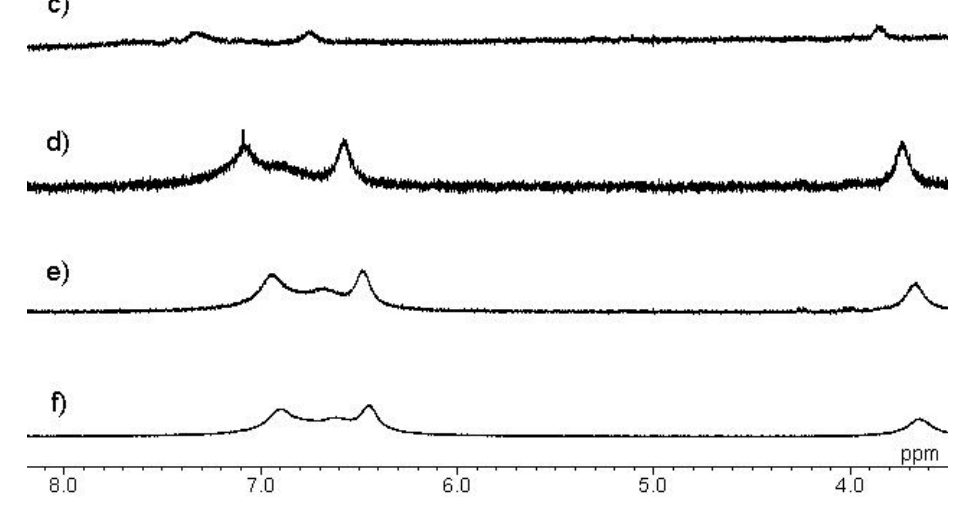

S-FIGURE 10. ${ }^{1} \mathrm{H}$ NMR spectra of $\mathbf{6 b}$ in cyclohexane- $d_{12}$ at $20{ }^{\circ} \mathrm{C}$ in the range of concentration of (a) 0.005 , (b) 0.01, (c) 0.05 , (d) 0.1, (e) 0.5, (f) $1.0 \mathrm{mM}$. 


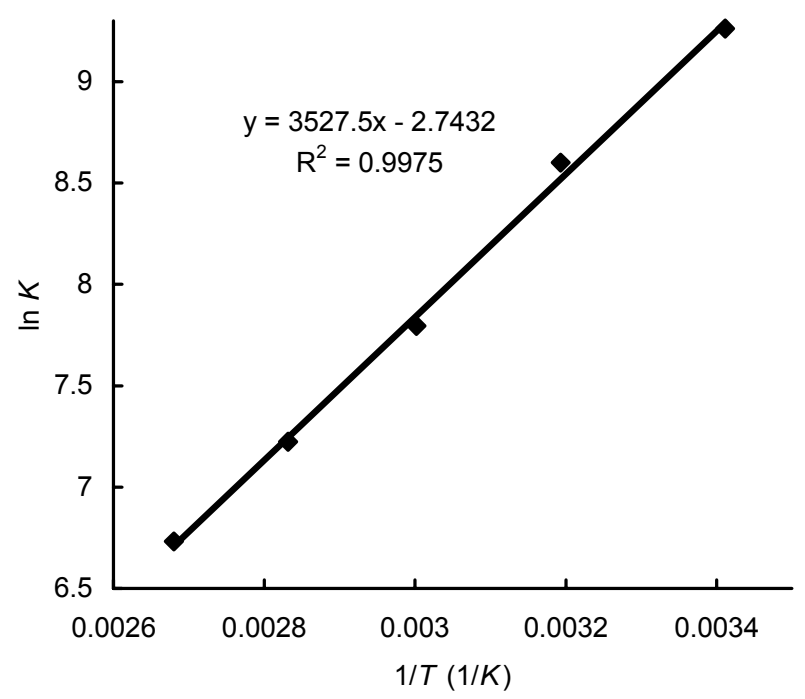

S-FIGURE 11. van't Hoff plot for the self-association of $\mathbf{6 c}$ in octane- $d_{18}$ : the correlation coefficient $(R)$ is 0.999 where $\Delta H^{0}$ is $-29.3 \mathrm{~kJ} \mathrm{~mol}^{-1}$ and $\Delta S^{0}$ is $-22.8 \mathrm{~J} \mathrm{~mol}^{-1} \mathrm{~K}^{-1}$.

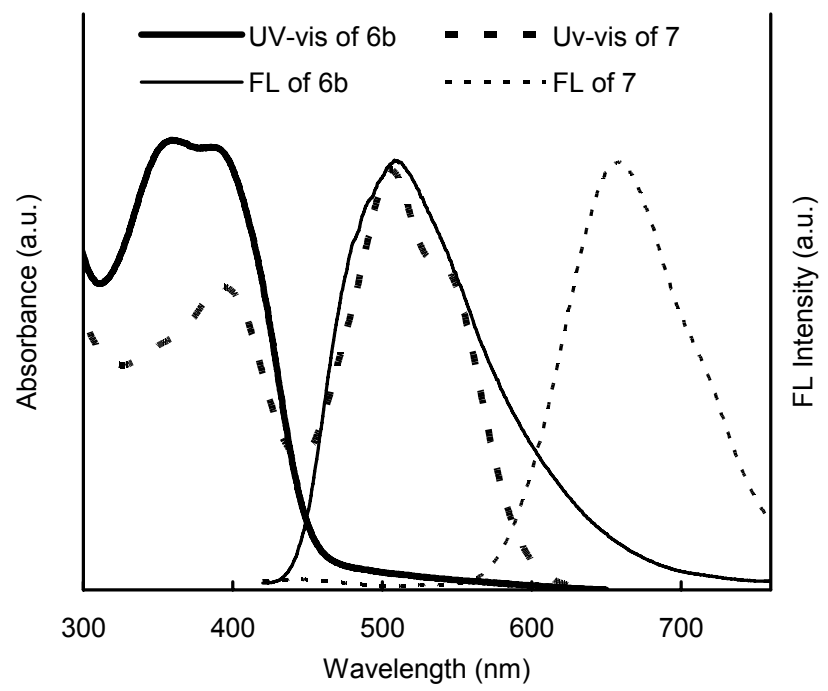

S-FIGURE 12. UV-vis and fluorescence spectra of $\mathbf{6 b}$ and 7 at the spin-coating film at $20{ }^{\circ} \mathrm{C}$. The fluorescence spectra were obtained by excitation at $395 \mathrm{~nm}$. 


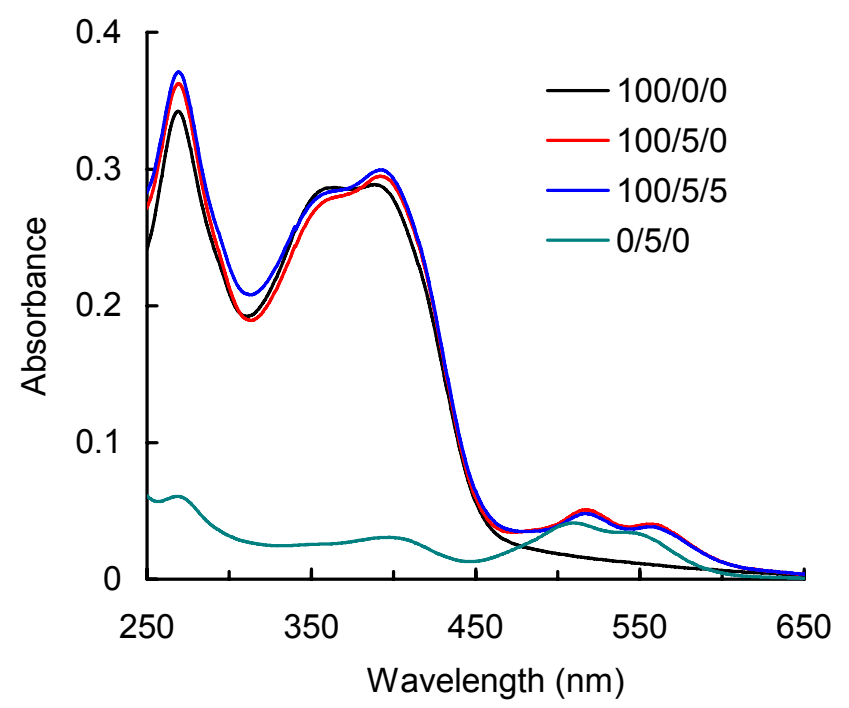

S-FIGURE 13. UV-vis spectra of 6a/7/8 mixtures with 100:0:0 (black line), 100:5:0 (red line), 100:5:5 (blue line), and 0:0:5 (green line) molar ratio in the spin-coating film at $20{ }^{\circ} \mathrm{C}$.

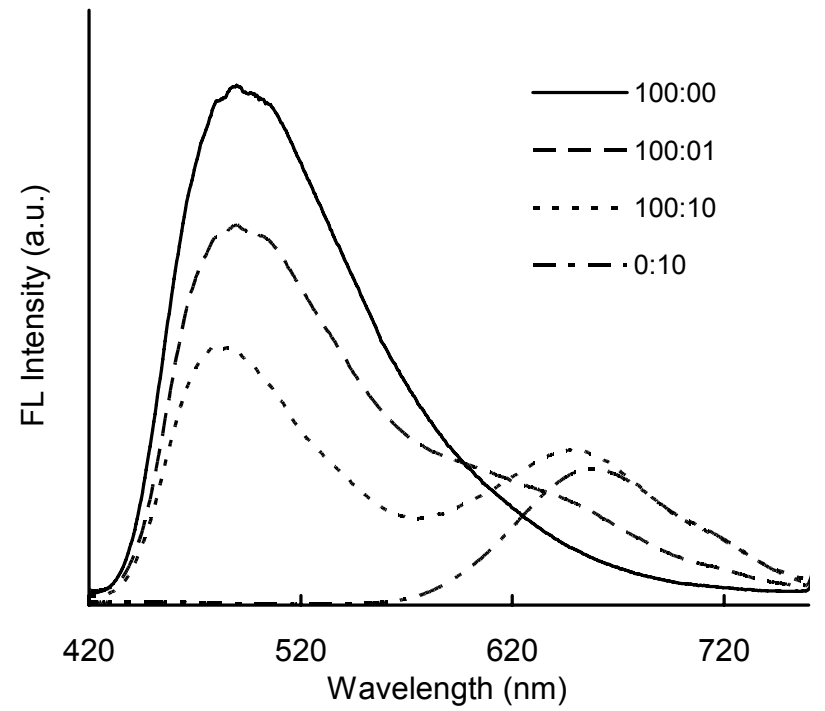

S-FIGURE 14. Fluorescence spectra excited at the HAT chromophore (395 nm) of $6 \mathbf{6 a} / \mathbf{7}$ mixtures with 100:0, 100:1, 100,10, and 0:10 molar ratio in the spin-coating film (from chloroform solution) at $20{ }^{\circ} \mathrm{C}$. 


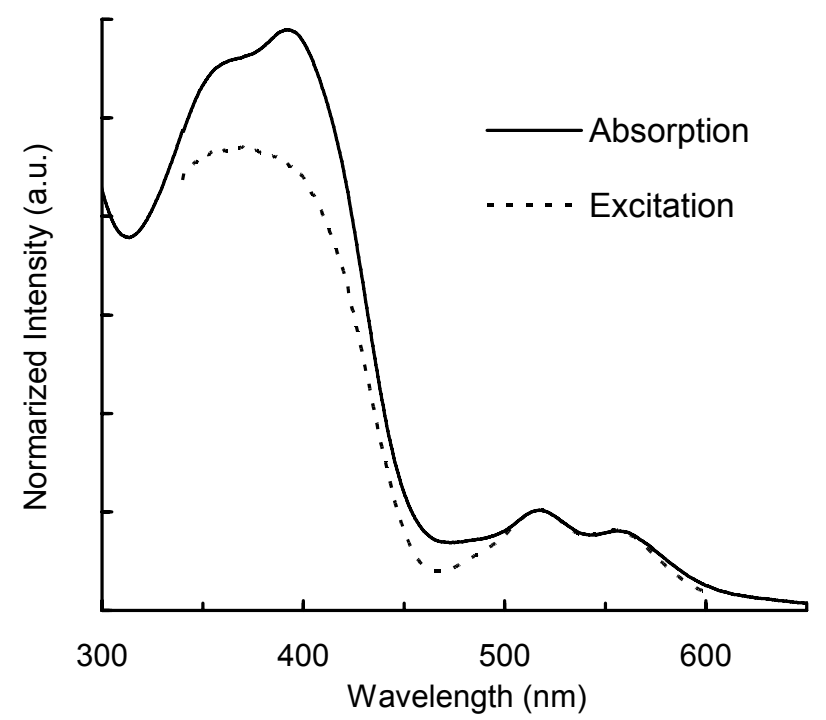

S-FIGURE 15. Absorption and excitation spectra of $\mathbf{6 a} / \mathbf{7}$ mixture with 100:5 at the spin-coating film (from cyclohexane solution) at $20{ }^{\circ} \mathrm{C}$. The excitation spectrum was monitored at the PDI chromophore (at $645 \mathrm{~nm}$ ). The energy transfer efficiency was estimated to be ca. $80 \%$. 
S-TABLE 1. UV-vis spectral data for $\mathbf{6 c}$ in octane.

\begin{tabular}{lll}
\hline temp $\left({ }^{\circ} \mathrm{C}\right)$ & conc $(\mathrm{mM})$ & $\lambda_{\max } / \mathrm{nm}\left(\varepsilon / \mathrm{M}^{-1} \mathrm{~cm}^{-1}\right)$ \\
\hline 20 & 1.0 & $347(73,000), 378(\mathrm{sh}, 66,000)$ \\
40 & 1.0 & $347(73,000), 378(\mathrm{sh}, 67,000)$ \\
60 & 1.0 & $347(73,000), 378(\mathrm{sh}, 69,000)$ \\
75 & 1.0 & $347(73,000), 378(71,000)$ \\
20 & 0.1 & $350(79,000), 381(78,000)$ \\
40 & 0.1 & $350(80,000), 382(83,000)$ \\
60 & 0.1 & $350(81,000), 384(89,000)$ \\
75 & 0.1 & $350(81,000), 385(90,000)$ \\
20 & 0.01 & $350(90,000), 388(100,000)$ \\
40 & 0.01 & $350(90,000), 388(110,000)$ \\
60 & 0.01 & $348(88,000), 388(100,000)$ \\
75 & 0.01 & $347(88,000), 388(100,000)$ \\
\hline
\end{tabular}

S-TABLE 2. Fluorescence lifetime for $\mathbf{6 a}$ (in hexane), $\mathbf{6 b}$ (in cyclohexane), and 6c (in hexane).

\begin{tabular}{lllll} 
compound & conc $(\mathrm{mM})$ & $\tau_{1} / \mathrm{ns}$ (population/\%) & $\tau_{2} / \mathrm{ns}$ (population/\%) & $\chi$ \\
\hline $\mathbf{6 a}^{a}$ & 1.0 & $1.99(49)$ & $5.98(51)$ & 1.068 \\
& 0.1 & $2.44(56)$ & $6.14(44)$ & 1.014 \\
& 0.01 & $2.04(49)$ & $5.28(51)$ & 0.977 \\
& 0.001 & $0.53(50)$ & $3.79(50)$ & 1.011 \\
$\mathbf{6 b}^{a}$ & 1.0 & $1.30(45)$ & $2.95(55)$ & 0.995 \\
& 0.1 & $1.14(43)$ & $2.54(57)$ & 0.999 \\
& 0.01 & $0.68(61)$ & $1.99(39)$ & 0.938 \\
& 0.001 & $0.50(91)$ & $1.36(9)$ & 0.927 \\
$\mathbf{6 c}^{a}$ & 1.0 & $0.57(14)$ & $2.22(86)$ & 1.015 \\
& 0.1 & $0.53(13)$ & $2.08(87)$ & 0.986 \\
& 0.01 & $0.44(45)$ & $1.80(55)$ & 0.973 \\
& 0.001 & $0.36(89)$ & $1.60(11)$ & 0.956 \\
$\mathbf{6 c}^{b}$ & 1.0 & 2.06 & & 1.102 \\
& 0.1 & 1.95 & & 1.046 \\
& 0.01 & 1.33 & & 1.289 \\
& 0.001 & 0.52 & & 1.022 \\
\hline
\end{tabular}

${ }^{a}$ Analyzed by double exponential. ${ }^{b}$ Analyzed by single exponential. 
General in Experimental Sections. All melting points are uncorrected. IR spectra were measured as $\mathrm{KBr}$ pellets. ${ }^{1} \mathrm{H}$ NMR spectra were determined in $\mathrm{CDCl}_{3}$ with 270 or $400 \mathrm{MHz}$ spectrometer. Residual solvent protons were used as internal standard and chemical shifts $(\delta)$ are given relative to tetramethylsilane (TMS). The coupling constants $(J)$ are reported in hertz $(\mathrm{Hz})$. Fast atom bombardment mass spectrometry (FAB-MS) spectra were recorded by using $m$-nitrobenzyl alcohol (NBA) as a matrix. Matrix assisted laser desorption ionization time-of-flight mass spectrometry (MALDI-TOF-MS) was performed by using delayed extraction mode and with an acceleration voltage of $20 \mathrm{keV}$. Samples were prepared from a solution of dichloromethane using dithranol as the matrix.

Gel permeation chromatography (GPC) was performed by using polystyrene gel column $(20 \times 600$ $\mathrm{mm}$ ) eluting with chloroform $\left(3.0 \mathrm{~mL} \mathrm{~min}^{-1}\right)$. Analytical TLC was carried out on silica gel coated on aluminum foil (Merck $60 \mathrm{~F}_{254}$ ). Column chromatography was carried out on silica gel (WAKO C300 or KANTO $60 \mathrm{~N}$ ). THF was distilled from sodium and benzophenone under an argon atmosphere just before use. Hexaaminobenzene trihydrochloride (5) was prepared according to a method reported previously. ${ }^{1} \quad$ Preparation of HAT derivatives $\mathbf{7}^{2}$ and $\mathbf{8}^{3}$ were reported previously. Compound $\mathbf{2 b}$ ' was prepared according to a method reported previously. ${ }^{4}$

4-Octyloxyphenylboronic acid (2b'): ${ }^{4}$ According to a method similar to the preparation of $\mathbf{2 a}, \mathbf{2} \mathbf{b}^{\text {' }}$ was obtained in $58 \%$ yield $(2.18 \mathrm{~g}, 8.7 \mathrm{mmol})$ from $\mathbf{1 b}(4.23 \mathrm{~g}, 15.0 \mathrm{mmol})$. The crude product was purified by reprecipitation from hexane. Without protection with 2,2-dimethyl-1,3-propanediol, crude 2b' was used to next reaction.

2,2-Dimethyl-1,3-propanediol 4-octylphenylboronate (2c): According to a method similar to the preparation of 2a, 2c was obtained in 65\% yield (3.66 g, $12.1 \mathrm{mmol})$ from 1c $(5.0 \mathrm{~g}, 18.6 \mathrm{mmol})$. The crude product was purified by silica gel column chromatography (KANTO 60N) eluting with chloroform/hexane $(1: 2, \mathrm{v} / \mathrm{v})$.

2,2-Dimethyl-1,3-propanediol 4-\{(S)-3,7-dimethyloctyloxy\}phenylboronate (2d): According to a method similar to the preparation of 2a, 2d was obtained in $47 \%$ yield (468 $\mathrm{mg}, 1.35 \mathrm{mmol}$ ) from 1d 
(900 mg, $2.9 \mathrm{mmol}$ ). The crude product was purified by silica gel column chromatography (KANTO $60 \mathrm{~N})$ eluting with chloroform/hexane $(1: 1, \mathrm{v} / \mathrm{v})$.

Bis(4'-octyloxybiphenyl-4-yl)ethanedione (4b): According to a method similar to the preparation of 4a, 4b was obtained in $83 \%$ yield $(515 \mathrm{mg}, 0.83 \mathrm{mmol})$ from 3 (368 $\mathrm{mg}, 1.0 \mathrm{mmol})$, tetrakis(triphenylphosphine)palladium(0) (115 mg, $0.1 \mathrm{mmol}, 5 \mathrm{~mol}-\%)$, benzene $(20 \mathrm{~mL}), 2 \mathbf{b}(500 \mathrm{mg}$, $2.2 \mathrm{mmol})$, ethanol $(5 \mathrm{~mL})$, and aqueous $2 \mathrm{M}$ sodium carbonate solution $(10 \mathrm{~mL})$. The crude product was purified by silica gel column chromatography (WAKO C300) eluting with chloroform/hexane (1:2, $\mathrm{v} / \mathrm{v})$.

Bis(4'-octylbiphenyl-4-yl)ethanedione (4c): According to a method similar to the preparation of 4a, 4c was obtained in $87 \%$ yield $(848 \mathrm{mg}, 1.45 \mathrm{mmol})$ from $3(613 \mathrm{mg}, 1.7 \mathrm{mmol})$, tetrakis(triphenylphosphine)palladium(0) $(115 \mathrm{mg}, 0.1 \mathrm{mmol}, 3 \mathrm{~mol}-\%)$, benzene $(30 \mathrm{~mL}), 2 \mathrm{c}(1.20 \mathrm{~g}$, $4.0 \mathrm{mmol})$, ethanol $(7.5 \mathrm{~mL})$, and aqueous $2 \mathrm{M}$ sodium carbonate solution $(15 \mathrm{~mL})$. The crude product was purified by silica gel column chromatography (WAKO C300) eluting with chloroform/hexane (1:1, $\mathrm{v} / \mathrm{v})$.

Bis\{4'-[(S)-3,7-dimethyloctyloxy]biphenyl-4-yl\}ethanedione (4d): According to a method similar to the preparation of $\mathbf{4 a}, \mathbf{4 d}$ was obtained in $88 \%$ yield $(297 \mathrm{mg}, 0.44 \mathrm{mmol})$ from 3 (189 $\mathrm{mg}, 0.5 \mathrm{mmol})$, tetrakis(triphenylphosphine)palladium(0) (40 mg, $0.035 \mathrm{mmol}, 3 \mathrm{~mol}-\%)$, benzene (10 mL), 2d (450 mg, $1.3 \mathrm{mmol})$, ethanol $(2.5 \mathrm{~mL})$, and aqueous $2 \mathrm{M}$ sodium carbonate solution $(5 \mathrm{~mL})$. The crude product was purified by silica gel column chromatography (WAKO C300) eluting with chloroform/hexane (1:1, $\mathrm{v} / \mathrm{v})$.

\section{2,3,6,7,10,11-Hexakis(4'-octyloxybiphenyl-4-yl)-1,4,5,8,9,12-hexaazatriphenylene}

(6b):

According to a method similar to the preparation of $\mathbf{6 a}, \mathbf{6 b}$ was obtained in $25 \%$ yield $(82 \mathrm{mg}, 0.043$ $\mathrm{mmol})$ from $4 \mathbf{b}(310 \mathrm{mg}, 0.5 \mathrm{mmol}), 5(47 \mathrm{mg}, 0.17 \mathrm{mmol})$, and acetic acid $(5 \mathrm{~mL})$. The crude product was purified by silica gel column chromatography (WAKO C300) eluting with chloroform/hexane (1:2, $\mathrm{v} / \mathrm{v}$ ) and by GPC (polystyrene JAIGEL-1H and 2H) eluting with chloroform. 
2,3,6,7,10,11-Hexakis(4'-octylbiphenyl-4-yl)-1,4,5,8,9,12-hexaazatriphenylene (6c): According to a method similar to the preparation of $\mathbf{6 a}, \mathbf{6 c}$ was obtained in $37 \%$ yield (162 $\mathrm{mg}, 0.12 \mathrm{mmol})$ from $\mathbf{4 c}$ (587 mg, $1.0 \mathrm{mmol}), 5(93 \mathrm{mg}, 0.33 \mathrm{mmol})$, and acetic acid $(25 \mathrm{~mL})$. The crude product was purified by silica gel column chromatography (WAKO C300) eluting with chloroform and by GPC (polystyrene JAIGEL-1H and 2H) eluting with chloroform.

\section{2,3,6,7,10,11-Hexakis \{4'-[(S)-3,7-dimethyloctyloxy]biphenyl-4-yl\}-1,4,5,8,9,12-hexaazatripheny}

lene (6d): According to a method similar to the preparation of $\mathbf{6 a}, \mathbf{6 d}$ was obtained in 17\% yield (53 mg, $0.025 \mathrm{mmol})$ from $4 \mathbf{d}(300 \mathrm{mg}, 0.44 \mathrm{mmol}), 5(41 \mathrm{mg}, 0.15 \mathrm{mmol})$, and acetic acid $(10 \mathrm{~mL})$. The crude product was purified by silica gel column chromatography (WAKO C300) eluting with chloroform/hexane (2:1, v/v) and by GPC (polystyrene JAIGEL-1H and 2H) eluting with chloroform.

\section{References}

(1) (a) Mataka, S.; Eguchi, H.; Takahashi, K.; Hatta, T.; Tashiro, M. Bull. Chem. Soc. Jpn. 1989, 62, 3127-3131. (b) Mataka, S.; Shimojyo, Y.; Hashimoto, I.; Tashiro, M. Liebigs Ann. 1995, 1823-1825. (c) Komin, A. P.; Carmack, M. J. Heterocyclic Chem. 1975, 12, 829-833.

(2) Ishi-i, T.; Murakami, K.; Imai, Y.; Mataka, S. Org. Lett. 2005, 7, 3175-3178.

(3) Ishi-i, T.; Hirayama, T.; Murakami, K.; Tashiro, H.; Thiemann, T.; Kubo, K.; Mori, A.; Yamasaki, S.; Akao, T.; Tsuboyama, A.; Mukaide, T.; Ueno, K.; Mataka, S. Langmuir 2005, 21, $1261-1268$.

(4) Artal, M. C.; Toyne, K. J.; Goodby, J. W.; Barberá, J.; Photinos, D. J. J. Mater. Chem. 2001, 11, 2801-2807. 